University of Nebraska - Lincoln

DigitalCommons@University of Nebraska - Lincoln

Faculty Publications, Department of Psychology

Psychology, Department of

2012

\title{
Diminished conditioned responding to the nicotine stimulus by antidepressant drugs with differing specificity for the serotonin and norepinephrine transporter
}

Amanda M. Dion

University of Nebraska-Lincoln

Scott C. Sanderson

University of Nebraska-Lincoln

L. Charles Murrin

University of Nebraska Medical Center

Rick A. Bevins

University of Nebraska-Lincoln, rbevins1@unl.edu

Follow this and additional works at: http://digitalcommons.unl.edu/psychfacpub

Part of the Psychology Commons

Dion, Amanda M.; Sanderson, Scott C.; Murrin, L. Charles; and Bevins, Rick A., "Diminished conditioned responding to the nicotine stimulus by antidepressant drugs with differing specificity for the serotonin and norepinephrine transporter" (2012). Faculty Publications, Department of Psychology. 751.

http://digitalcommons.unl.edu/psychfacpub/751

This Article is brought to you for free and open access by the Psychology, Department of at DigitalCommons@University of Nebraska - Lincoln. It has been accepted for inclusion in Faculty Publications, Department of Psychology by an authorized administrator of DigitalCommons@University of Nebraska - Lincoln. 


\title{
Diminished conditioned responding to the nicotine stimulus by antidepressant drugs with differing specificity for the serotonin and norepinephrine transporter
}

\author{
Amanda M. Dion ${ }^{a}$, Scott C. Sanderson ${ }^{a}$, L. Charles Murrin ${ }^{b}$, and Rick A. Bevins ${ }^{a, \varpi}$ \\ aDepartment of Psychology, University of Nebraska-Lincoln, Lincoln NE, 68588-0308, USA \\ bDepartment of Pharmacology and Experimental Neuroscience, University of Nebraska Medical \\ Center, Omaha, NE, 68198, USA
}

\section{Abstract}

People diagnosed with depression also tend to have a co-morbid nicotine addiction. Thus, there is interest in whether medications used to treat depression alter the effects of nicotine. This study assessed whether the antidepressant drugs citalopram, imipramine, and reboxetine, with differing specificity for the serotonin and norepinephrine transporter, altered responding controlled by the conditional stimulus (CS) effects of nicotine. Rats received intermixed 20-min nicotine ( $0.4 \mathrm{mg}$ base $/ \mathrm{kg}, \mathrm{SC}$ ) and saline sessions. On nicotine sessions, rats had intermittent access to sucrose; no sucrose was available on saline sessions. After discrimination performance stabilized and a nicotine generalization curve $(0.025-0.4 \mathrm{mg} / \mathrm{kg})$ was established, the antidepressant drugs were assessed. In these tests, rats were pretreated with citalopram (1-17 mg/kg), imipramine (1-17 mg/ $\mathrm{kg}$ ), or reboxetine $(1-30 \mathrm{mg} / \mathrm{kg}$ ) before the training dose of nicotine and placement in a chamber for a 4-min extinction test. At the higher doses, all three antidepressant drugs blocked responding evoked by the nicotine CS and decreased nicotine-induced hyperactivity. When these higher doses of citalopram, imipramine, and reboxetine were tested alone (no nicotine), they decreased chamber activity and/or dipper entries. Nevertheless, all three drugs produced partial or complete blockade of the CS effects of nicotine at doses that produced no effect on dipper entries or chamber entries. This finding suggests that both neurotransmitters play a role in the CS effects of nicotine and that modifications in these systems by antidepressants may be clinically relevant.

\section{Keywords}

nicotine; selective serotonin reuptake inhibitor; selective noradrenaline reuptake inhibitor; Pavlovian drug discrimination; reboxetine; citalopram; imipramine

\section{Introduction}

Despite the common knowledge that tobacco use and its associated nicotine dependence is harmful and causes premature death, over 440,000 people still die each year in the United

\footnotetext{
(C) 2011 Elsevier Inc. All rights reserved.

${ }^{\square}$ Address Correspondence and Reprint Requests to: Rick A. Bevins, Department of Psychology, University of Nebraska-Lincoln, Lincoln, NE 68588-0308, USA, Phone: 402\472-1189, FAX: 402\472-4637, rbevins1@unl.edu.

Publisher's Disclaimer: This is a PDF file of an unedited manuscript that has been accepted for publication. As a service to our customers we are providing this early version of the manuscript. The manuscript will undergo copyediting, typesetting, and review of the resulting proof before it is published in its final citable form. Please note that during the production process errors may be discovered which could affect the content, and all legal disclaimers that apply to the journal pertain.
} 
States as a result of that addiction (Mackay and Erikson, 2002). Nearly 70\% of current smokers express a desire to quit. However, the ability to remain abstinent longer than one month continues to challenge many individuals, with most relapsing within one week (NIDA, 2009). The societal cost of cigarette smoking is increasing exponentially with current annual costs in the U.S. exceeding $\$ 193$ billion (NIDA, 2009). Clearly, from a personal and a societal perspective there is great need to further explore and develop more efficacious cessation programs. Tailoring treatment programs to target populations is one possible approach (Chua et al., 2011). Of particular interest in the present report are individuals diagnosed with depression. Research indicates that $40-60 \%$ of people with depression have a co-morbid nicotine addiction (Anda et al., 1990; Glassman, 1993; Hall et al., 1993; Hughs et al., 1986; Matthew et al., 1981). Given the high co-morbidity, there is interest in whether medications used to treat depression such as selective serotonin reuptake inhibitors (SSRI) and/or selective norepinephrine reuptake inhibitors (SNRI) also alter the effects of nicotine (cf. Weinberger et al., 2010).

Along these lines, our laboratory has evaluated the effects of two antidepressant drugs (bupropion and atomoxetine) on nicotine-evoked conditioned responding in a Pavlovian drug discrimination task (Reichel et al., 2007; Wilkinson et al., 2010). In those studies, rats had intermixed nicotine and saline sessions. On nicotine sessions, rats had intermittent access to liquid sucrose across the 20-min session; no sucrose was available on saline sessions. The nicotine conditional stimulus (CS) in this task comes to evoke anticipatory seeking of the sucrose [i.e., goal-tracking (Farwell and Ayres, 1979)]. In the study by Wilkinson et al. (2010), bupropion at $20 \mathrm{mg} / \mathrm{kg}$ evoked a goal-tracking conditioned response comparable to the training dose of nicotine $(0.4 \mathrm{mg}$ base $/ \mathrm{kg})$. This result indicates that bupropion, also known as the smoking cessation aid Zyban ${ }^{\circledR}$ and the antidepressant Wellbutrin ${ }^{\circledR}$, shares stimulus properties with nicotine. Of note, pretreatment with $20 \mathrm{mg} / \mathrm{kg}$ bupropion before nicotine administration blocked the conditioned responding evoked by the nicotine CS (Wilkinson et al., 2010). This antagonism of the CS effects of nicotine may reflect the nicotinic antagonist and/or the norepinephrine reuptake inhibition effects of bupropion (Ascher et al., 1995; Miller et al., 2002; Slemmer et al., 2000). Related to this latter effect, Reichel et al. (2007) demonstrated that the antidepressant drug atomoxetine (Strattera ${ }^{\circledR}$ ), a potent SNRI (Viggiano et al., 2004), partially blocked the goal-tracking conditioned response evoked by a $0.2 \mathrm{mg}$ base/ $\mathrm{kg}$ nicotine CS (Reichel et al., 2007).

Given these findings and the co-morbidity of smoking with depression (Weinberger et al., 2010), the present study examined the effects of clinically used antidepressants that have a different profile of action on the serotonin versus norepinephrine transporter. To this end, we evaluated whether reboxetine (Edronax ${ }^{\circledR}$ ), a potent SNRI similar to atomoxetine (Wong et al., 2000; Simpson and Perry, 2003), blocked nicotine-evoked conditioned responding. We also evaluated imipramine (Tofranil®), a combined SSRI and SNRI, and citalopram (Celexa®), a potent SSRI (Owens et al., 1997) and their effects on responding controlled by CS effects of nicotine.

\section{Methods}

\subsection{Subjects}

Sixteen male Sprague-Dawley rats (weighing $278 \pm 2 \mathrm{~g}$ at the start of the study) were obtained from Harlan (Indianapolis, IN USA). Rats were individually housed in clear polycarbonate cages $[48.3 \times 26.7 \times 20.3 \mathrm{~cm}(1 \times \mathrm{w} \times \mathrm{h})]$ lined with wood shavings in a temperature- and humidity-controlled room on a $12 \mathrm{~h}$ light:dark cycle; all experimental sessions were conducted during the light portion of the cycle. Water was continuously available in the home cage. Chow access was restricted to maintain rats at $85 \%$ of their freefeeding weight. Approximately every 30 days, the target weight was increased by $2 \mathrm{~g}$. 
Experimental protocols were approved by the University of Nebraska-Lincoln Institutional Animal Care and Use Committee and followed the "Guide for the Care and Use of Laboratory Animals" (National Research Council, 1996).

\subsection{Apparatus}

Eight conditioning chambers (Med-Associates, Georgia, VT USA) were used in this study. Each chamber was enclosed in a light and sound attenuating polyvinylchloride cubicle fitted with a fan to provide airflow and mask noise. The conditioning chambers measured $30.5 \times$ $24.1 \times 21 \mathrm{~cm}(1 \times \mathrm{w} \times \mathrm{h})$. The sidewalls were made of aluminum; the ceiling, front, and back walls were clear polycarbonate. Each chamber was equipped with a recessed dipper receptacle $(5.2 \times 5.2 \times 3.8 \mathrm{~cm} ; 1 \times \mathrm{w} \times \mathrm{d})$ in one aluminum sidewall. When the dipper arm was raised, it allowed access to $0.1 \mathrm{ml}$ of $26 \%$ sucrose solution (w/v) in the receptacle. An infrared emitter/detector unit located $1.2 \mathrm{~cm}$ inside the receptacle and $3 \mathrm{~cm}$ from the rod floor recorded head entries. A second infrared emitter/detector unit located $14.5 \mathrm{~cm}$ from the sidewall containing the receptacle and $4 \mathrm{~cm}$ above the rod floor provided a measure of general chamber activity. A personal computer with Med Associates interface and software (Med-PC for Windows, version IV) timed the sessions, recorded beam breaks for dipper entries and chamber crosses, and presented the sucrose.

\subsection{Drugs}

(-)-Nicotine hydrogen tartrate and imipramine hydrochloride were purchased from Sigma (St. Louis, MO, USA). Reboxetine mesylate and citalopram hydrobromide were purchased from Tocris (Ellisville, MO USA). All drugs were dissolved in $0.9 \%$ saline solution, and injected at a volume of $1 \mathrm{ml} / \mathrm{kg}$. Nicotine was injected subcutaneously (SC), and imipramine, reboxetine, and citalopram were injected intraperitoneally (IP). Drug doses and injection-to-placement intervals were selected based on past research (Besheer et al., 2004; Dekeyne et al., 2001; Marona-Lewicka and Nichols, 1998; Millan et al., 2001; Murray and Bevins, 2007a,b; Ortman and Meisburger, 1986; Rauhut et al., 2002). For each testing phase, a unique testing order was used for each rat. A dilute $\mathrm{NaOH}$ solution was used to adjust the $\mathrm{pH}$ of the nicotine solution to $7.0 \pm 0.2$. Nicotine doses are reported in the base form; all other drug doses are reported in the salt form.

\subsection{Discrimination Training}

Before the start of the experiment, all rats were handled for about 2 min each for 3 days. For the 3 days immediately preceding acquisition, all rats were given one injection of the training dose of nicotine $(0.4 \mathrm{mg} / \mathrm{kg})$ per day in the home cage to attenuate the initial locomotor suppressant effects of nicotine (cf. Bevins et al., 2001). Daily training sessions began the day following the last home cage nicotine injection. Rats were injected with nicotine $(0.4 \mathrm{mg} / \mathrm{kg})$ or $0.9 \%$ saline $5 \mathrm{~min}$ before placement in the conditioning chamber for a 20-min session. For each nicotine sessions, there were 36 separate 4-s presentation of sucrose. The time to the first sucrose delivery and the inter-sucrose interval were varied across four different computer programs. The average time before the first sucrose delivery across programs was $137 \mathrm{~s}$ with a range of 124-152 s. On intermixed saline sessions, sucrose deliveries were withheld. Order of nicotine and saline sessions were randomly assigned to each rat with the restriction that no more than two of the same session type (nicotine or saline) occurred in a row. There were 12 nicotine and 12 saline training sessions before the start of testing.

\subsection{Testing}

After the discrimination was acquired, rats entered a testing phase that consisted of repeating five day cycles. The first four days of each cycle were continued training sessions (2 
nicotine and 2 saline sessions) as described earlier to ensure maintenance of the discrimination. If a rat met the testing criterion (see later), then a 4-min extinction test session occurred in place of a normal training session on day five; sucrose was withheld during test sessions. If a rat did not meet the criterion, then it remained in the home cage for that day. Table 1 shows the progression of test phases, as well as the ligand and doses under study. All doses within a phase were completed before the next phase began.

2.5.1. Nicotine generalization-Nicotine generalization testing immediately followed acquisition of the discrimination. On test days, rats were injected with the assigned dose of nicotine or saline 5 min before a 4-min extinction test (see Table 1). Each rat had a unique testing order and all doses of nicotine were evaluated before moving to the antagonism phase.

\subsubsection{Reboxetine, citalopram, and imipramine antagonism of nicotine-}

Following completion of the nicotine generalization phase, testing cycles continued as previously described. For an antagonism test, a rat was pretreated with its assigned dose of reuptake inhibitor or saline at the prescribed injection-to-placement interval (IPI); nicotine was then administered $5 \mathrm{~min}$ before the 4-min test (see Table 1). Given two different IPIs (15 or $30 \mathrm{~min}$ ), pretreatment with the saline solution was tested twice; once at each IPI. Timing of saline pretreatment did not affect conditioned responding evoked by nicotine $(p>0.05)$. Accordingly, the mean of the two scores for each rat was used for analyses (see later). As before, each rat had a unique testing order.

\subsubsection{Reboxetine, citalopram, and imipramine substitution-Following} completion of the antagonism phase, testing cycles continued as previously described. Substitution tests were similar to antagonism tests except saline rather than nicotine was administered 5 min before each of the 4-min tests. Testing order of reuptake inhibitor was fixed as shown in Table 1. Based on the findings with atomoxetine by Reichel et al. (2007), we did not expect these antidepressants to substitute for the nicotine CS. Accordingly, testing order was fixed because the goal of testing the reuptake inhibitor alone was to determine whether attenuation of nicotine-evoked conditioned responding in the previous antagonism phase reflected, at least in part, a non-specific effect of the drug interfering with goal-tracking (see Discussion). Hence, we start with the highest dose of a reuptake inhibitor that blocked conditioned responding and then moved to a lower dose if an effect was detected.

\subsection{Dependent measures and testing criterion}

The primary dependent measure of conditioning was the rate of infrared beam breaks in the dipper receptacle per second before the first sucrose delivery during nicotine sessions or equivalent time during saline or test sessions. In order to qualify to test, dipper entry rate on each nicotine session had to be at least 0.01 entries per second higher than each saline session of that testing cycle (cf. Murray and Bevins, 2007a). General chamber activity was defined as the number of chamber beam breaks per second during the same intervals as dipper entries.

\subsection{Data analyses}

For acquisition training, a paired-samples t-test was used to compare the average dipper entry rate on nicotine versus saline sessions for the last three days of training. For generalization and antagonism testing phases, dipper entries and chamber activity for each compound were analyzed with separate one-way repeated measures ANOVAs. Significant one-way ANOVAs were also followed with pair-wise comparisons using Fisher's LSD minimum mean difference (mmd) tests. For substitution tests, each drug/dose combination was 
compared with the last saline value from the 5-day testing cycle using a paired-samples ttest. Statistical significance was declared using $\mathrm{p}<0.05$ for all tests.

\section{Results}

One rat was removed from this experiment after the nicotine generalization phase because it did not maintain the nicotine-saline discrimination. Two other rats were not tested at a single drug/dose combination in the substitution phase due to inconsistencies in meeting testing criterion at that point in the study (see Table 1 for the number of rats per phase).

\subsection{Discrimination Training}

Rats readily acquired the drug discrimination (data not shown) with nicotine differentially evoking a goal-tracking conditioned response. The mean dipper entry rate $( \pm$ SEM) across the last 3 nicotine sessions $(0.17 \pm 0.022)$ was significantly higher than that on saline sessions $(0.07 \pm 0.008), \mathrm{t}(15)=5.78, \mathrm{p}<0.001$.

\subsection{Testing}

3.2.1. Nicotine generalization-Figure $1 \mathrm{~A}$ shows the mean dipper entry rate for the nicotine generalization phase. Nicotine-evoked conditioned responding was sensitive to test dose [Dose main effect, $F(5,75)=12.19, \mathrm{p}<0.001]$. There was a higher rate of dipper entries at $0.05,0.1,0.2$, and $0.4 \mathrm{mg} / \mathrm{kg}$ nicotine than saline $\left(\mathrm{LSD}_{\mathrm{mmd}}=0.044\right)$. Furthermore, the rate of dipper entries at 0.025 and $0.05 \mathrm{mg} / \mathrm{kg}$ were lower than the $0.4 \mathrm{mg} / \mathrm{kg}$ training dose of nicotine. As displayed in Figure 1B, chamber activity increased with nicotine dose [Dose main effect, $F(5,75)=23.33, p=0.001]$. Activity counts were higher at 0.2 and $0.4 \mathrm{mg} / \mathrm{kg}$ nicotine than saline $\left(\mathrm{LSD}_{\mathrm{mmd}}=0.067\right)$. Activity at the nicotine training dose was higher than all other doses.

3.1.2. Reboxetine, citalopram, and imipramine antagonism of nicotine-Panels $\mathrm{A}, \mathrm{B}$, and $\mathrm{C}$ of Figure 2 show conditioned responding evoked by nicotine after pretreatment with reboxetine, citalopram, or imipramine, respectively. There was a main effect of Dose for reboxetine, $F(5,70)=10.26$, $\mathrm{p}<0.001$, with reboxetine blocking nicotine-evoked responding to saline levels at the $30 \mathrm{mg} / \mathrm{kg}$ dose $\left(\mathrm{LSD}_{\mathrm{mmd}}=0.04\right)$. This reduction in dipper entries was partial at 3,10 , and $17 \mathrm{mg} / \mathrm{kg}$ with responding lower than the nicotine training dose, but still significantly higher than saline. There was a main effect of Dose with citalopram, $F(6,84)=9.35, p<0.001$. Conditioned responding was reduced to saline levels at 10 and $17 \mathrm{mg} / \mathrm{kg}\left(\mathrm{LSD}_{\mathrm{mmd}}=0.04\right)$; blockade of responding was partial at $7.8 \mathrm{mg} / \mathrm{kg}$. The main effect of Dose was also significant for imipramine, $F(4,56)=11.12$, $\mathrm{p}<0.001$. Dipper entries were fully blocked by $17 \mathrm{mg} / \mathrm{kg}\left(\mathrm{LSD}_{\mathrm{mmd}}=0.04\right)$ and partially reduced at $10 \mathrm{mg} / \mathrm{kg}$.

Panels A, B, and C of Figure 3 show nicotine-induced activity after pretreatment with reboxetine, citalopram, or imipramine, respectively. For reboxetine, there was a significant main effect of Dose, $F(5,70)=7.53, \mathrm{p}<0.001$. At 10,17 , and $30 \mathrm{mg} / \mathrm{kg}$, nicotine-induced hyperactivity was lowered to saline levels $\left(\mathrm{LSD}_{\mathrm{mmd}}=0.076\right)$. For citalopram, there was a main effect of Dose, $\mathrm{F}(6,84)=8.10$, $\mathrm{p}<0.001$; pretreatment with $17 \mathrm{mg} / \mathrm{kg}$ citalopram reduced the locomotor stimulant effect of nicotine to saline levels $\left(\mathrm{LSD}_{\mathrm{mmd}}=0.095\right)$. For imipramine, there was a significant effect of Dose, $F(4,56)=10.90, p<0.001$. Nicotine-induced activity was fully blocked by $17 \mathrm{mg} / \mathrm{kg}$ imipramine $\left(\mathrm{LSD}_{\mathrm{mmd}}=0.08\right)$.

3.1.3. Reboxetine, citalopram, and imipramine substitution-Table 2 displays the dipper entries and chamber activity from the substitution tests. Recall that nicotine was not administered after pretreatment with the assigned dose of drug in this phase. Thus, these tests provide a measure of the non-specific effects of each ligand on dipper entries and 
chamber activity. For reboxetine, dipper entries at 10 and $30 \mathrm{mg} / \mathrm{kg}$ were significantly below saline, ts(14) $\geq 2.47$, ps $\geq 0.027$. Dipper entries at $17 \mathrm{mg} / \mathrm{kg}$ did not differ from saline, $\mathrm{t}<1$. Activity at all doses of reboxetine $(10,17$, and $30 \mathrm{mg} / \mathrm{kg}$ ) was significantly below saline, ts $(14) \geq 2.27$, ps $\geq 0.039$. For citalopram, dipper entries were below saline levels only at the 17 $\mathrm{mg} / \mathrm{kg}$ dose, $\mathrm{t}(14)=3.76, \mathrm{p}=0.002$. However, activity was not affected by either dose of citalopram, ts $<1$. For imipramine, dipper entries at $10 \mathrm{mg} / \mathrm{kg}$ was significantly lower than saline, $\mathrm{t}(13)=5.36, \mathrm{p}<0.001$; a comparable decrease was not seen at $17 \mathrm{mg} / \mathrm{kg}, \mathrm{t}(14)=1.28$, $\mathrm{p}=0.22$. Activity at $10 \mathrm{mg} / \mathrm{kg}$ of imipramine was significantly lower than saline, $\mathrm{t}(13)=2.59$, $\mathrm{p}=0.022$. Further, there was a tendency for reduced activity at $17 \mathrm{mg} / \mathrm{kg}, \mathrm{t}(14)=2.11$, $\mathrm{p}=0.053$.

\section{Discussion}

As noted earlier, there is high co-morbidity between chronic smoking and depressive symptoms (e.g., Weinberger et al., 2010). As such, there is interest in whether medications used to treat depression may also alter the effects of nicotine. Along these lines, earlier work by Reichel et al. (2007) found that atomoxetine ( 1 to $10 \mathrm{mg} / \mathrm{kg}$ ) partially antagonized nicotine-evoked conditioned responding; nicotine-induced hyperactivity was also reduced to saline levels with pretreatment of 3 or $10 \mathrm{mg} / \mathrm{kg}$ atomoxetine (see later). Consistent with these findings, Gould et al. (2005) found that atomoxetine $(2 \mathrm{mg} / \mathrm{kg})$ blocked nicotine $(0.125$ $\mathrm{mg} / \mathrm{kg}$ ) enhancement of prepulse inhibition of the acoustic startle response in mice. Atomoxetine has also been shown to attenuate context fear conditioning deficits of mice induced by withdrawal from nicotine (Davis and Gould, 2007). Further, pretreatment with reboxetine decreased self-administration of nicotine in rats; reboxetine did not affect general chamber activity in that self-administration study (Rauhut et al., 2002).

Given this research, along with the bupropion work discussed in the Introduction (see also Wilkinson et al., 2010), the present study sought to evaluate whether other antidepressant drugs with varying affinity for the noradrenergic versus serotonergic transporter, reboxetine (SNRI), imipramine (mixed SSRI and SNRI), and citalopram (SSRI), would block the interoceptive stimulus effects of nicotine. Pretreatment with any of the three reuptake inhibitors blocked conditioned responding evoked by the nicotine CS and decreased nicotine-induced hyperactivity. Although this outcome suggests a role for both serotonin and norepinephrine in the CS effects of nicotine, a detailed analysis of the action of these ligands alone in the substitution tests suggests a more cautious/complex interpretation should be considered. That is, reboxetine and imipramine alone, both of which block norepinephrine reuptake, at doses that blocked the effects of nicotine also decreased chamber activity and dipper entries relative to saline. Citalopram alone, which blocks serotonin reuptake, did not significantly affect general chamber activity, but it did attenuate dipper entries to a level below that of saline. Nevertheless, all three drugs produced a partial or complete blockade of the effects of nicotine at doses that, in our hands, produced no significant effect on dipper entries or chamber entries. This suggests that both neurotransmitters play a role in the CS effects of nicotine and that modifications in these systems by antidepressants may be clinically relevant.

These potential non-specific effects suggest that motor impairment (reboxetine and imipramine) and/or a decrease in the incentive value of the goal or its associated stimuli (reboxetine, imipramine, and citalopram) also contribute to the decreased conditioned responding to the nicotine CS. This latter possibility is considered given that the average dipper entry rate on saline sessions in this study, as well as our other published studies using this training protocol (e.g., Murray et al., 2007b; Reichel et al., 2010), is always above 0 . This observation suggests that there is some residual goal-tracking controlled by a learned association between the stimuli that compose the dipper receptacle and sucrose and/or by the 
sucrose and its olfactory cues that are still present on saline sessions (i.e., sucrose inaccessible, but present in the dipper well).

Although the self-administration and fear conditioning work described earlier did not find evidence for such non-specific effects, other reports have found such effects with the ligands used in the present study (e.g., Dekeyne et al., 2002; Evenden, 1998; Martin et al., 1982). Dekeyne et al. (2002), for example, found that reboxetine and imipramine decreased lever pressing rate maintained by food reinforcement. In that same study, food intake was decreased by citalopram when assessed outside the experimental chambers used to measure schedule-controlled responding. Consistent with these latter studies, in the report by Reichel et al. (2007), dipper entries were decreased by pretreatment with the highest dose of atomoxetine $(10 \mathrm{mg} / \mathrm{kg})$ alone. Given that this observation was isolated to the $10 \mathrm{mg} / \mathrm{kg}$ dose, and the 1 and $3 \mathrm{mg} / \mathrm{kg}$ dose also partially blocked nicotine-evoked responding without altering dipper entries when given alone, little was made of that observation in that paper. However, the present results suggest that the results from this earlier report should be interpreted with the same complexity regarding blockade of the CS effects of nicotine along with attenuation of the incentive value of sucrose or its associated stimuli (e.g., receptacle).

Regarding this interpretive complexity, it was recently suggested that decreased dipper entries by reboxetine, imipramine, and citalopram in the saline session may not reflect diminished incentive value of the goal or its associated stimuli. Rather, saline (i.e., nonnicotine state) should be considered a CS-; a stimulus that indicates the absence of the reinforcer. Procedurally, saline is clearly a CS- in this discriminated goal-tracking task [or a negative drug feature; see Bevins and Murray (2011)]. Whether saline as a CS- is behaviorally similar to more widely studied exteroceptive stimuli remains untested (cf., Murray et al., 2011; Rescorla, 1969). This CS- account reframes the interpretation of the decreased dipper entries by the antidepressant, suggesting that it reflects an enhancement of these CS- effects (i.e., processes involved in response inhibition).

The present research was not designed to dissociate between the different accounts the substitution tests findings with the antidepressants. Regardless, the findings here, and elsewhere, on serotonin and/or norepinephrine transporters suggests that such ligands should be considered within the framework of treating depressed individuals that have co-morbid nicotine dependence. However, the evidence for potential non-specific effects suggests that care should be taken to sufficiently evaluate the effects of these pharmacotherapies and how they not only alter smoking behavior and associated urges, but also adherence to medication regimens.

\section{Acknowledgments}

We thank Nicole Wells for her help in conducting the research described in this report. The notion of antidepressants enhancing CS- effects of saline (no-drug state) was suggested by an anonymous reviewer. The research and R. A. Bevins were supported by United States Public Health Service Grant DA018114. All MED-PC programs used in the present article are available in an updated form upon request.

\section{References}

Ascher JA, Cole JO, Colin JN, Feighner JP, Ferris JP, Fibiger HC, Golden RN, Martin P, Potter WZ, Richelson E, Sulser F. Bupropion: a review of its mechanism of antidepressant activity. J Clin Psychiatry. 1995; 56:395-401. [PubMed: 7665537]

Anda RF, Williamson DF, Escobedo LG, Mast EE, Giovino GA, Remington PL. Depression and the dynamics of smoking. JAMA. 1990; 264:1541-5. [PubMed: 2395193] 
Besheer J, Palmatier MI, Metschke DM, Bevins RA. Nicotine as a signal for the presence or absence of sucrose reward: a Pavlovian drug appetitive conditioning preparation in rats. Psychopharmacology. 2004; 172:108-17. [PubMed: 14530902]

Bevins RA, Besheer J, Pickett KS. Nicotine-conditioned locomotor activity in rats: dopaminergic and GABAergic influences on conditioned expression. Pharmacol Biochem Behav. 2001; 68:135-45. [PubMed: 11274718]

Bevins, RA.; Murray, JE. Internal stimuli generated by abused substances: Role of Pavlovian conditioning and its implications for drug addiction. In: Schachtman, TR.; Reilly, S., editors. Associative Learning and Conditioning: Human and Non-Human Applications. New York, NY: Oxford University Press; 2011. p. 270-289.

Chua HF, Ho SS, Jasinska AJ, Polk TA, Welsh RC, Liberzon I, Strecher V. Self-related neural response to tailored smoking-cessation message predicts quitting. Nature Neuroscience. 2011; 14:426-7.

Davis JA, Gould TJ. Atomoxetine reverses nicotine withdrawal-associated deficits in contextual fear conditioning. Neuropsychopharmacology. 2007; 32:2011-9. [PubMed: 17228337]

Dekeyne A, Gobert A, Auclair A, Girardon S, Millan MJ. Differential modulation of efficiency in a food-rewarded "differential reinforcement of low-rate" 72-s schedule in rats by norepinephrine and serotonin reuptake inhibitors. Psychopharmacology. 2002; 162:156-67. [PubMed: 12110993]

Dekeyne A, Gobert A, Iob L, Cistanelli L, Melon C, Millan MJ. Discriminative stimulus properties of the selective norepinephrine reuptake inhibitor, reboxetine, in rats. Psychopharmacology. 2001; 154:213-8. [PubMed: 11314684]

Evenden JL. The pharmacology of impulsive behaviour in rats II: the effects of amphetamine, haloperidol, imipramine, chlordiazepoxide and other drugs on fixed consecutive number schedules (FCN 8 and FCN 32). Psychopharmacology. 1998; 138:283-94. [PubMed: 9725750]

Farwell BJ, Ayres JJB. Stimulus-reinforcer and response-reinforcer relations in the control of conditioned appetitive headpoking ("goal tracking") in rats. Learning and Motivation. 1979; 10:295-312.

Glassman AH. Cigarette smoking: implications for psychiatric illness. Am J Psychiatry. 1993; 150:546-53. [PubMed: 8465868]

Gould TJ, Rukstalis M, Lewis MC. Atomoxetine and nicotine enhance prepulse inhibition of acoustic startle in C57BL/6 mice. Neuroscience Letters. 2005; 377:85-90. [PubMed: 15740842]

Hall SM, Munoz RF, Reus VI, Sees KL. Nicotine, negative affect and depression. J Consul Clin Psychol. 1993; 61:761-7.

Hughes JR, Hatsukami DK, Mitchell JE, Dahlgreen LA. Prevalence of smoking among psychiatric outpatients. Am J Psychiatry. 1986; 143:993-7. [PubMed: 3487983]

Kalman D, Morrissette SB, George TP. Co-morbidity of smoking in patients with psychiatric and substance use disorders. Am J Addict. 2005; 14:106-23. [PubMed: 16019961]

Mackay, J.; Eriksen, M. Tobacco Atlas. London: World Health Organization, Hanway Press; 2002.

Marona-Lewicka D, Nichols DE. Drug discrimination studies of the interoceptive cues produced by selective serotonin uptake inhibitors and selective serotonin releasing agents. Psychopharmacology. 1998; 138:67-75. [PubMed: 9694528]

Martin JR, Oettinger R, Driscoll P, Buzzi R, Bättig K. Effects of chlordiazepoxide and imipramine on maze patrolling within two different maze configurations by psychogenetically selected lines of rats. Psychopharmacology. 1982; 78:58-62. [PubMed: 6815698]

Matthew RJ, Weinman ML, Mirabi M. Physical symptoms of depression. Br J Psychiatry. 1981; 139:293-6. [PubMed: 7326538]

Millan MJ, Dekeyne A, Papp M, La Rochelle CD, MacSweeny C, Peglion JL, Brocco M. S33005, a novel ligand at both serotonin and norepinephrine transporters: II. Behavioral profile in comparison with venlafaxine, reboxetine, citalopram, and clomipramine. J Pharmacol Exp Ther. 2001; 298:581-91. [PubMed: 11454919]

Millan MJ, Dekeyne A. Discriminative stimulus properties of the selective norepinephrine reuptake inhibitor, reboxetine, in rats: a characterization with $\alpha / \beta$-adrenoreceptor subtype selective ligands, antidepressants, and antagonists at neuropeptide receptors. Int J Neuropsychopharm. 2007; 10:579-93. 
Miller DK, Sumithram SP, Dwoskin LP. Bupropion inhibits nicotine-evoked [3H] overflow from rat striatal slices preloaded with $[3 \mathrm{H}]$ dopamine and from rat hippocampal slices preloaded with [3H]norepinephrine. J Pharmacol Exp Ther. 2002; 302:1113-22. [PubMed: 12183670]

Murray JE, Bevins RA. Behavioral and neuropharmacological characterization of nicotine as a conditional stimulus. Eur J Pharmacol. 2007a; 561:91-104. [PubMed: 17343849]

Murray JE, Bevins RA. The conditional stimulus effects of nicotine vary as a function of training dose. Behav Pharmacol. 2007b; 18:707-16. [PubMed: 17989508]

Murray JE, Walker AW, Li C, Wells NR, Penrod RD, Bevins RA. Nicotine trained as a negative feature passes the retardation-of-acquisition and summation tests of a conditioned inhibitor. Learning \& Memory. 2011; 18:452-8. [PubMed: 21693633]

National Institute of Drug Abuse (NIDA). Research Report Series: Tobacco Addiction. 2009. Available from: http://www.drugabuse.gov/PDF/TobaccoRRS_v16.pdf

National Research Council. Guide for the Care and Use of Laboratory Animals. Washington, DC: National Academy Press; 1996.

Ortmann R, Meisburger JG. Rolipram forms a potent discriminative stimulus in drug discrimination experiments in rats. Psychopharmacology. 1986; 89:273-7. [PubMed: 3014592]

Owens MJ, Morgan WN, Plott SJ, Nemeroff CB. Neurotransmitter receptor and transporter binding profile of antidepressants and their metabolites. J Pharmacol Exp Ther. 1997; 283:1305-22. [PubMed: 9400006]

Rauhut AS, Mullins SN, Dwoskin LP, Bardo MT. Reboxetine: attenuation of intravenous nicotine selfadministration in rats. J Pharmacol Exp Ther. 2002; 303:664-72. [PubMed: 12388649]

Reichel CM, Linkugel JD, Bevins RA. Nicotine as a conditioned stimulus: impact of attention-deficit/ hyperactivity disorder medications. Exp Clin Psychopharmacol. 2007; 15:501-9. [PubMed: 17924784]

Reichel CM, Murray JE, Barr JD, Bevins RA. Extinction with varenicline and nornicotine, but not ABT-418, weakens conditioned responding evoked by the interoceptive stimulus effects of nicotine. Neuropharmacology. 2010; 58:1237-45. [PubMed: 20302882]

Rescorla RA. Pavlovian conditioned inhibition. Psychol Bull. 1969; 72:77-94.

Simpson D, Perry CM. Atomoxetine. Pediatric Drugs. 2003; 5:407-15. [PubMed: 12765489]

Slemmer JE, Martin BR, Damaj MI. Bupropion is a nicotinic antagonist. J Pharmacol Exp Ther. 2000; 295:321-27. [PubMed: 10991997]

Weinberger AH, McKee SA, Picciotto MR, Mazure CM. Examining antidepressant drug response by smoking status: why is it important and how often is it done? J Psychopharm. 2010 Dec 17. [Epub ahead of print].

Wilkinson JL, Carroll FI, Bevins RA. An investigation of bupropion substitution for the interoceptive stimulus effects of nicotine. J Psychopharm. 2010; 24:817-28.

Wong EHF, Sonders MS, Amara SG, Tinholt PM, Piercey MFP, Hoffmann WP, Hyslop DK, Franklin S, Porsolt RD, Bonsignori A, Carfagna N, McArthur RA. Reboxetine: A pharmacologically potent, selective, and specific norepinephrine reuptake inhibitor. Biol Psychiatry. 2000; 47:81829. [PubMed: 10812041] 


\section{Highlights}

- Nicotine acquired differential control of goal-tracking conditioned response

- Antidepressant drugs citalopram, imipramine, and reboxetine blocked conditioned responding

- Stimulus effects of nicotine appear to involve the noradrenergic and serotonergic systems

- At some doses antidepressant drugs alone alter chamber activity and/or dipper entries

- motor effects or a decrease in incentive value of sucrose also contributes to decreased responding 

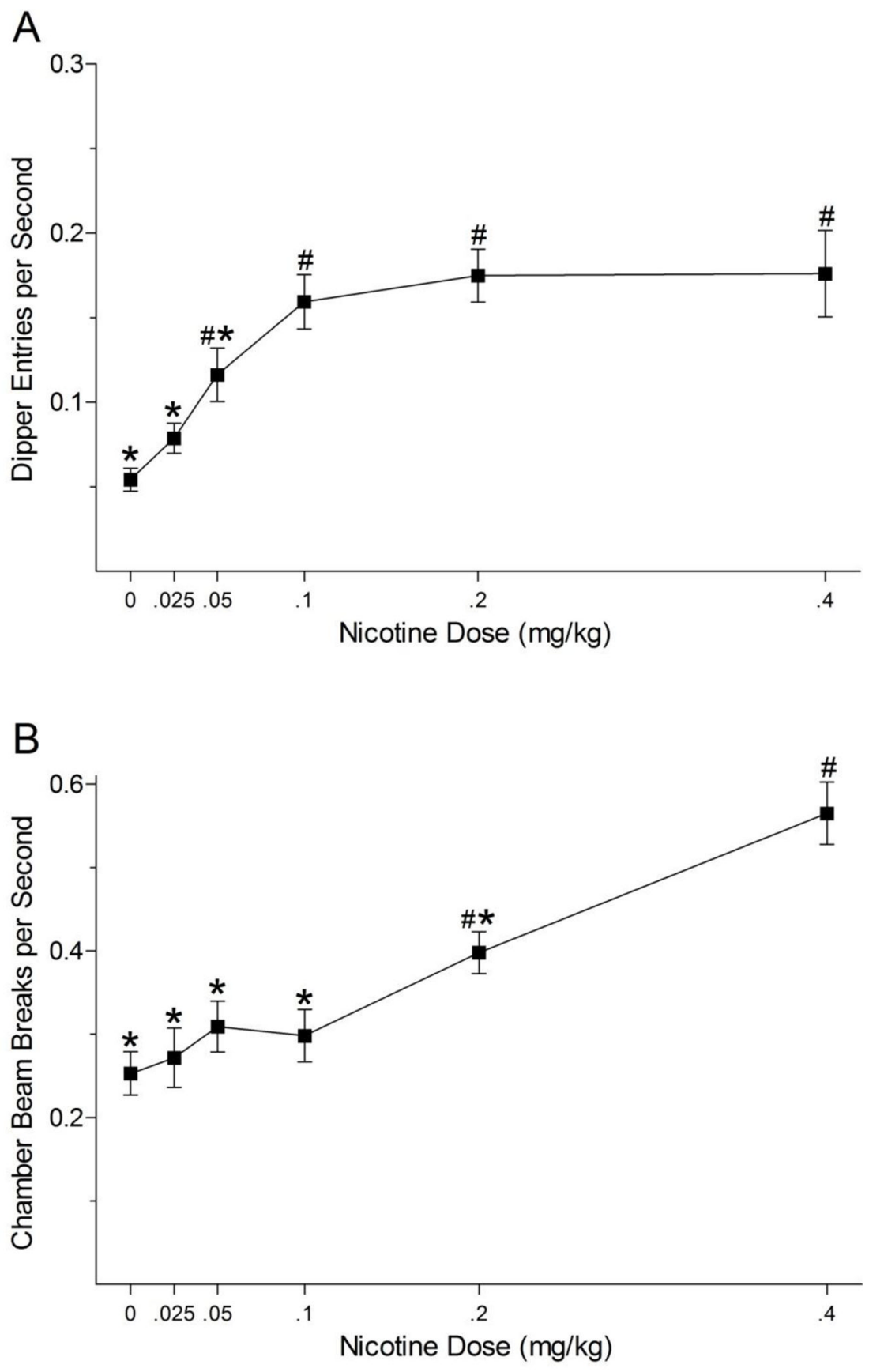

Figure 1.

Panel A shows the mean $( \pm$ SEM) dipper entry rates during nicotine generalization testing. Panel B shows the mean ( \pm SEM) chamber beam breaks per second (activity) during nicotine generalization testing. \# denotes a significant difference $(\mathrm{p}<0.05)$ from saline; * denotes a significant difference from the training dose of nicotine $(0.4 \mathrm{mg} / \mathrm{kg})$. 

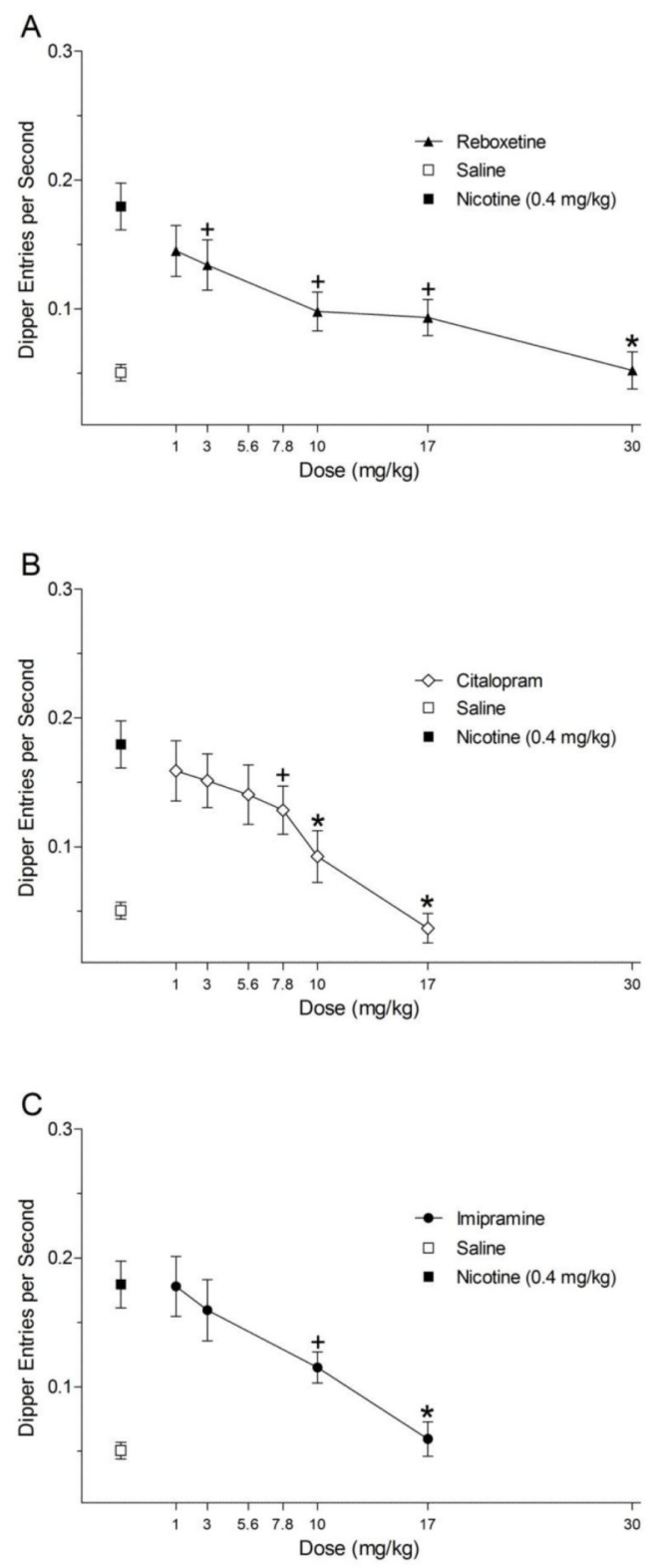

Figure 2.

Panels A, B, and C show the mean ( \pm SEM) dipper entry rates during reboxetine, citalopram, and imipramine antagonism testing, respectively, of nicotine evoked conditioned responding. * denotes a significant difference $(\mathrm{p}<0.05)$ from nicotine, but not saline (i.e., full blockade); + denotes a significant difference from nicotine and saline (i.e., partial blockade). 

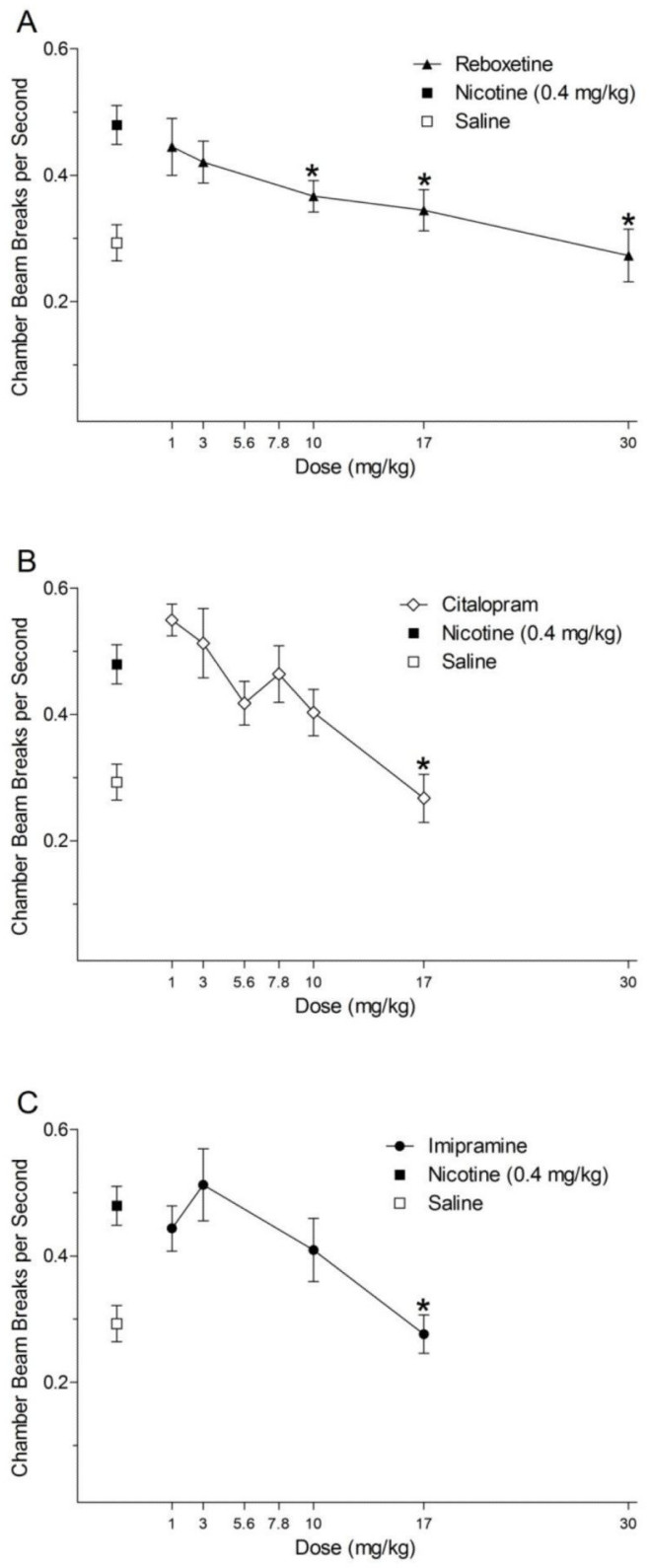

Figure 3.

Panels A, B, and C show the mean ( \pm SEM) chamber beam breaks per second (activity) during reboxetine, citalopram, and imipramine antagonism testing, respectively. ${ }^{*}$ denotes a significant difference $(\mathrm{p}<0.05)$ from nicotine, but not saline (i.e., full blockade). 
Table 2

Dipper entries and activity for substitution tests.

\begin{tabular}{lcc}
\hline Drug & Dipper Entries $/ \mathrm{sec}($ Mean \pm SEM) & Chamber Beam Breaks $/$ sec (Mean \pm SEM) \\
\hline Saline & $.048 \pm .008$ & $.256 \pm .025$ \\
Reboxetine $(10 \mathrm{mg} / \mathrm{kg})$ & $.028 \pm .004^{*}$ & $.157 \pm .024^{*}$ \\
Saline & $.038 \pm .006$ & $.293 \pm .037$ \\
Reboxetine $(17 \mathrm{mg} / \mathrm{kg})$ & $.031 \pm .006$ & $.156 \pm .027^{*}$ \\
Saline & $.050 \pm .010$ & $.225 \pm .042$ \\
Reboxetine $(30 \mathrm{mg} / \mathrm{kg})$ & $.021 \pm .004^{*}$ & $.144 \pm .016^{*}$ \\
\hline Saline & $.040 \pm .005$ & $.302 \pm .043$ \\
Citalopram $(10 \mathrm{mg} / \mathrm{kg})$ & $.030 \pm .005$ & $.246 \pm .040$ \\
Saline & $.037 \pm .004$ & $.231 \pm .021$ \\
Citalopram $(17 \mathrm{mg} / \mathrm{kg})$ & $.009 \pm .005^{*}$ & $.211 \pm .025$ \\
\hline Saline & $.033 \pm .004$ & $.285 \pm .037$ \\
Imipramine $(10 \mathrm{mg} / \mathrm{kg})$ & $.017 \pm .003^{*}$ & $.177 \pm .024^{*}$ \\
Saline & $.040 \pm .006$ & $.298 \pm .054$ \\
Imipramine $(17 \mathrm{mg} / \mathrm{kg})$ & $.032 \pm .006$ & $.176 \pm .019$ \\
\hline * & & \\
significant difference from saline & & \\
\end{tabular}

